\title{
THE ECONOMETRIC MODEL FOR ASSESSING THE ECONOMIC CATEGORY OF A RUSSIAN FARMER ENTREPRENEUR IN TERMS OF THE "INNOVATOR VS. CONSERVATIVE" SYSTEM
}

\author{
Alexander Semin \\ Ural State Economic University, Yekaterinburg, Russian Federation \\ Mikhail Kislitskiy \\ All-Russian Research Institute of Agricultural Economics, Moscow, Russian Federation
}

\begin{abstract}
The slowdown in agricultural growth in Russia determines the development of an innova-tion base for expanding exports. Therefore, the formation of a new social class of farmers-entrepreneurs, focused on the implementation of innovative activities, becomes relevant. The aim of the study was to develop an econometric model for assessing the economic types of farmers-entrepreneurs according to the system "innovator versus conservative" using the example of the agro-industrial complex. The questionnaire method was used to determine the levels of innovative development of the respondents. The survey was conducted from October 2017 to December 2019; 900 farmers from Tver, Kursk, Tambov, Penza, Arkhangelsk, Kurgan, Leningrad regions, as well as Yakutia took part in it. Using the method of cluster analysis, all classes (categories) of farmers-entrepreneurs are determined by the level of innovation. Depending on the type of enterprise, clas-sification functions of farmers have been developed. As a result, the structure of the agribusiness environment in Russia was determined.
\end{abstract}

Keywords: agriculture, farmers, entrepreneurs, innovators, conservatives, Russia, innovative development

DOI: http://dx.doi.org/10.15549/jeecar.v7i3.597

\section{INTRODUCTION}

Agriculture is one of the priority sectors of the Russian economy. Its development is actively supported by the state, both at the macro and micro levels. Thus, $75 \%$ of the profits of the Agro-Industrial Complex (AIC) companies were subsidized by the state over the past four years (Avksent'ev et al., 2019). At the beginning of 2019, federal budget of the Russian Federation allocated 248 billion rubles in terms of the State Program of Agricultural Development and Regulations for Markets of Agricultural Products, Raw Materials and Food. That is 2.5\% more than was planned (Deloitte, 2019). For the first half of 2019, almost 131.7 billion rubles were used, which is $43.7 \%$ of the budget allocations planned in the Program for 2019. The largest share of the funds was involved for the support of the subprogram "Development of 
agricultural sectors" (77\%) (Deloitte, 2019). Despite the active support of the agricultural industry by government, the business assessment of the industry has become less positive compared with 2018. The index value has decreased by 14 points, which is to the value of 0.26 (Deloitte, 2019). The share of agriculture in Gross Domestic Product (GDP) in real terms decreased by 0.2 percentage points over the year and amounted to $4.1 \%$, while the share of GDP in current prices decreased by 0.4 percentage points. In addition, at the end of 2019, agriculture showed a negative trend ($2.1 \%$ ), decreasing by 3.5 percentage points compared to 2018 (Avksent'ev et al., 2019). Import substitution and a sharp increase in exports have become the main objectives of the agrarian policy of the recent years (The Russian Government, 2012). Only high rates of industry development would contribute to the achievement of the goals for export growth and import substitution. According to the results of the study, conducted by the analytical company Deloitte, there were two key factors determining the AIC development in Russia in 2019. The first factor reflects the level of government support for the industry. In this aspect, the State program of integrated development of rural territories provides the increase in federal budget expenditures on rural development from 79 to 1057 billion rubles (13.4 times) (Deloitte, 2019). The second factor is the development of the production and technical potential of the industry (Shutkov, 2019; Buzdalov, 2016). To ensure the second factor, the foresight of scientific and technological development of the agroindustrial complex of the Russian Federation for the period until 2030 has been developed. That means that in modern conditions, the development of agriculture depends on an effective innovation policy, whose goal is to introduce advanced technologies, inventions, forms of labor organization and production management based on the achievements of scientific and technological progress (Nikolaeva, 2014; Mazur et al., 2016; Gunyakov \& Gunyakov, 2013).

It should be noted that farm enterprise is the most dynamically developing sector of Russian agriculture. More than 205 thousand farms annually increase agricultural production.
Alongside with private farms, entrepreneurs produce up to $48 \%$ of agricultural products in the country (TASS Russian News Agency, 2020). The analysis of the entrepreneurial activity in the agricultural sector in developed countries shows that, even in terms of risky activities, they play a leading innovative role in the development of high-tech production and the innovations implementation in the industry (Xie et al., 2019; Kostyaev, 2018). Without the implementation of innovations, which provide the automation of agricultural activities and the formation of a new class of innovative farmers, it is impossible to ensure the scientific and technological development of the agricultural sector in Russia. The participation of a farmer entrepreneur in innovative processes is determined by the psychology, namely by the particular personal qualities and the assigned roles in innovation management. Therefore, the main objective of this study was to determine the qualitative characteristics and categories of farmers by the example of the entrepreneurs in Russian regions. The research was based on the innovative theory of Schumpeter. Another goal of the study was to determine the main quantitative levels of categories of farmer entrepreneur in the "innovator vs. conservative" system and the structure of farmer entrepreneurs in the current economic conditions and to justify the consequences for the industry and the region.

\section{LITERATURE REVIEW}

As a rule, entrepreneurs as economic agents provide the development of innovation in economic sectors. For the first time, the fundamental features of an entrepreneur as a subject of innovation were studied in the works of the French economist Jean-Baptiste Say (Say, 2018), who believed that an entrepreneur should create new methods of production and management, as well as understand people and take risks. According to Peter Drucker (19092005), a well-known American management researcher (Drucker, 2008), entrepreneurs are able to find an economic resource where others do not notice it. They try to create opportunities in the process of their professional activities and business development. 
A number of scientists studied innovations development in economic sectors by means of evolutionary theory within the "innovator vs. conservator" system (Newman et al., 2018; Jones \& Barnir, 2019; Neneh, 2019). An important role for the success of innovations in any sphere of the economy and in agriculture, in particular, is assigned to so-called innovators (Adukov \& Aidinova, 2016; Sharapova, 2017). These are people who voluntarily support and promote the innovations. They actively seek new ideas, turn them into innovations and bring them to market. People who actively and intensively encourage innovations in the field of economics have been the focus of research for more than fifty years (Schon, 1963; Witte, 1977; Maidique, 1980; Markham, 2000; Aeeni et al., 2019; Zaremohzzabieh et al., 2019; Mthanti \& Ojah, 2017; Youssef, Boubaker \& Omri, 2018; Dvouletý, 2018).

According to Schumpeter (2008), in terms of market economy, the entrepreneur innovator is the motive power of changes that unbalance the economic system. In the context of innovations implementation, the usual order is changed by innovative entrepreneurs, who drive the conservatives out from economic interactions and occupy the vacant spaces. However, both "innovators" and "conservatives" perform a certain positive function in economic activity. The presence of "conservatives" allows us to identify and define innovation. In addition, they ensure the preservation of existing standards until the "innovators" activity contributes to the transition to new standards, which gradually become more attractive. The total cost of the "conservative" is lower than the costs of the "innovator" (Schumpeter, 2008).

Entrepreneurship is based on systematic innovation, i.e. search and implementation of new opportunities to meet human desires and needs. The entrepreneur's participation in innovative processes is determined by psychology. Firstly, the entrepreneurs tend for creativity and innovation. This makes them look for new ideas and implement them. In general, most researchers admit that innovative entrepreneurs have the following personal characteristics: the need for autonomy and independence, optimism, motivation, responsibility, professional adherence, leadership, self-organization, self-identification, flexibility and communicativeness, rationalism, and individualism.

The analysis of scientific literature also shows that personal characteristics of a conservative entrepreneur can be classified according to the following traits: absolutism, pessimism, traditionalism, archaism, awareness, antiindividualism, anti-rationalism, and ideologism (Newman et al., 2018; Jones \& Barnir, 2019; Neneh, 2019; Cipollone \& Giordani, 2019; Paul \& Shrivatava, 2016; Klein, 2016).

At the micro-level, the problem of the evolution of the "innovator vs. conservative" system is reduced to the coexistence of these groups of agents within a single economic organization, namely, the company that has both "innovators" and "conservatives" (Newman et al., 2018). In these terms, new products and markets are being developed, although "old" items are also being produced. This combination provides a certain safety margin for the company, contributes to the effective distribution of resources and, finally, has a positive effect on the development of the organization (Novikova et al., 2016; Al-Hashimy, Al Jubair \& Jasim, 2019; Vu et al., 2019). At the macro-level of the economic system, the main issue is to find the most appropriate combination of the number of "innovators" and "conservatives". It should be noted that most scientists admit priority of "innovators" in the dichotomy "innovators vs. conservatives" (Newman et al., 2018). Since "innovators" act as the generators of economic progress, therefore, economic policy should ensure not only the emergence of new "innovators", i.e. stimulate innovation, but also support this model of behavior. The economic roles of entrepreneurs are significant for the successful implementation of innovations in the industry and in the economy as a whole. The only problem is that in order to encourage an innovative model of the economic agents' behavior, an effective state policy should be provided. The authors of the present study highlight the necessity of the assessment of the entrepreneurs' innovative potential in the entire economy or in a specific sector. It was observed that these aspects were considered by scientists only in terms of economic theory. Thus, the 
researchers determined the motivations of the behavior of "innovator vs. conservative" system and the results of changes in the behavior of economic objects. The authors of the present study consider that an effective model of innovations development requires the formation of an approach for identifying the type of entrepreneur in the economy.

\section{METHODS AND MATERIALS}

The methodology of the study was based on the method of questioning, cluster and discriminant analysis. The survey involved 900 farmers of Tver, Kursk, Tambov, Penza, Arkhangelsk, Kurgan, and Leningrad regions, as well as Yakutia. The goal of the research was to study the innovation level, to determine the socio-economic characteristics of the innovator and to obtain quantitative estimates for the development of the model for innovation level identification.

Statistical universe with a confidence interval of $95 \%$ is regarded as a sufficient sample, which is presented by a sampling frame of 273 people. The research involved farmers from the regions with medium innovation level (Roscongress, 2018). In the regions selected for the study, the deviation from the average indicator of innovation in Russia is 101.8\% (Roscongress, 2018). The sufficiency of the sample is confirmed by the compliance with the requirements for the size of the sample (with a possible deviation of $1.8 \%$ ). The research involved farmers of different age categories, marital status, level of education, fields of activity, and regions, characterizing the innovation level in Russia. Therefore, the results of the present research characterize the innovation level in the entire country. The socio-economic characteristics of the innovator, a model for identifying the innovation level, and the distribution of farmers by innovation level are universal for Russia.

The survey was conducted in person in several stages from October 2017 to December 2019.

Table 1. Reliability of the questionnaire to determine the category of farmer entrepreneur within the "innovator vs. conservative" system.

\begin{tabular}{|c|c|c|}
\hline Indicator & Question & $\begin{array}{l}\text { Alpha If } \\
\text { Deleted }\end{array}$ \\
\hline \multicolumn{3}{|c|}{ The First Block } \\
\hline$X 1.1$ & How old are you? & 0.87 \\
\hline$X 1.2$ & Place of birth? & 0.88 \\
\hline$X 1.3$ & How many siblings do you have? & 0.87 \\
\hline$X 1.4$ & Are you married? & 0.88 \\
\hline$X 1.5$ & Do you have any children? & 0.9 \\
\hline$X 1.6$ & How many children do you have? & 0.9 \\
\hline$X 1.7$ & What is your education level? & 0.87 \\
\hline$X 1.8$ & What did you major in? & 0.86 \\
\hline$X 1.9$ & What area do you work in? & 0.87 \\
\hline$X 1.10$ & Are you related to agriculture? & 0.85 \\
\hline$X 1.11$ & $\begin{array}{l}\text { Rate from } 1 \text { to } 10 \text { the frequency of laptop use, where } 1 \text { is "very rare" and } 10 \text { is } \\
\text { "constantly". }\end{array}$ & 0.86 \\
\hline$X 1.12$ & $\begin{array}{l}\text { Rate from } 1 \text { to } 10 \text { the frequency of tablet use, where } 1 \text { is "very rare" and } 10 \text { is } \\
\text { "constantly". }\end{array}$ & 0.88 \\
\hline$X 1.13$ & $\begin{array}{l}\text { Rate from } 1 \text { to } 10 \text { the frequency of smartphone use, where } 1 \text { is "very rare" and } 10 \\
\text { is "constantly". }\end{array}$ & 0.87 \\
\hline$X 1.14$ & How many hours a day do you spend online? & 0.83 \\
\hline$X 1.15$ & How many hours a day do you watch TV? & 0.87 \\
\hline
\end{tabular}


X2.1 Rate from 1 to 10 the ability to make decisions independently and reasonably, where 1 is "not capable", 10 is "able to make decisions independently".

Rate from 1 to 10 the necessity to make decisions at work, where 1 is "do not have to make such decisions", 10 is "always have to make decisions".

Rate from 1 to 10 your satisfaction with the decisions you made, where 1 is "not satisfied", 10 is "completely satisfied".

Rate from 1 to 10 the interest in your business development, where 1 is "not interested", 10 is "very interested".

X2.5 Rate from 1 to 10 your reliability, where 1 is "not reliable", 10 is "reliable".

Rate from 1 to 10 whether you are ready to bear responsibility for your actions, where 1 is "not ready", 10 is "ready".

Rate from 1 to 10 your professional adherence, where 1 is "not adherent, I can easily change my field of activity", 10 is "adherent".

Rate from 1 to 10 your readiness to develop your business until the last, where 1 is "not ready", 10 is "ready".

Rate from 1 to 10 your comfort as a leader, where 1 is "not comfortable", 10 is "comfortable".

Rate from 1 to 10 whether you are respected by colleagues and friends, where 1 is "not respected", 10 is "respected".

Rate from 1 to 10 how good you are at time management, where 1 is "not good", 10 is "good".

Rate from 1 to 10 whether you are able to plan your time, where 1 is "not capable", 10 is "capable".

X.13 "not capable", 10 is "capable".

Rate from 1 to 10 whether your self-esteem (about your personal and professional qualities, place in business development) corresponds to your colleagues' opinion, where 1 is "personal opinion does not correspond to the colleagues' opinion", 10 is "personal opinion corresponds to the colleagues' opinion".

Rate from 1 to 10 whether you are able to avoid conflicts, where 1 is "not capable", 10 is "capable".

X2.16 Rate from 1 to 10 how adaptive you are to changing business conditions, where 1 is "not adaptive", and 10 is "adaptive".

Rate from 1 to 10 how easy it is to establish interpersonal contact, where 1 is "hard" and 10 is "easy".

Rate from 1 to 10 how effective you are in communicating with people, where 1 is "not effective", 10 is "effective".

Rate from 1 to 10 your disturbance about the losses after a well-planned financial compensate for the losses".

Rate from 1 to 10 the degree of satisfaction with the results of your work, where 1 is "the lowest level of satisfaction", and 10 is "the highest".

$X 2.21$ Rate from 1 to 10 the level of your happiness, where 1 is "zero level of happiness", and 10 is "the maximum level of happiness".

Rate from 1 to 10 the importance of trust in your life, where 1 is "means nothing", 
The respondents were asked to answer questions regarding their social and demographic, professional characteristics, and innovation development (Table 1). The first block of questions tends to determine the social and economic characteristics of the innovator. The second block of questions is devoted to the study of innovation level according to the criteria which were identified by means of the scientific literature analysis, namely: autonomy (indicators $X 2.1, X 2.2)$, responsibility $(X 2.5$, $X 2.6)$, professional adherence $(X 2.4, X 2.7, X 2.8)$, leadership $(X 2.9, X 2.10)$, rationality $(X 2.11$, $X 2.12)$, self-identification $(X 2.3, X 2.13, X 2.14)$, flexibility, adaptability $(X 2.15, X 2.16)$, communicativeness $(X 2.17, X 2.18)$, optimism (X2.19-X2.2)[14-16,29-31].

The quality of the presented questionnaire was evaluated by means of the Cronbach's alpha. For its calculation the values of the indicators $X 1.2, X 1.7-X 1.9$ were converted to ordinal data, the values of the indicators $X 1.4$, $X 1.5, X 1.10$ to binary ones. To calculate the coefficient, the program Statistica 12.0 was used. The calculated value of the Cronbach's alpha for the first block was 0.87 , for the second block 0.91. These values confirm the internal consistency of the questionnaire, its ability to describe the social and economic portrait of a modern Russian farmer-entrepreneur (Block 1) and the level of innovation (Block 2). The values of the coefficient are introduced in Table 1.

For the indicators $X 1.2, X 1.4-X 1.6, X 1.12, X 2.1$, $X 2.5, X 2.13, X 2.18$ the values of the Cronbach's alpha are higher than the average. On the one hand, if these indicators and corresponding questions are excluded from the questionnaire, it will be more consistent. However, it may lead to the loss of informational content. Since the total coefficient is high ( 0.87 for the 1 st block, 0.91 for the 2nd) and the questionnaire is consistent, these issues were not excluded from the questionnaire.

The cluster analysis (Neskorodeva \& Pustovgar, 2015) was conducted to determine the level of innovation development among the Russian farmers (by the example of the farmers of Tver, Kursk, Tambov, Penza, Arkhangelsk, Kurgan, Leningrad regions, and Yakutia).
The results of a survey according to the second block formed the statistical base. The authors studied the entire spectrum of innovation levels and developed a universal model for determination of the innovation level in Russia. For this purpose, the source data set was supplemented with two observations, such as: the first one corresponds to the minimum possible values of indicators $X 2.1-X 2.22$ (1 point each), and the second, which corresponds to the potential level of innovation development, i.e., 10 points for indicators $X 2.1-X 2.22$. Thus, the number of variables was 22, observations 902 . To determine the number of clusters and their characteristics, the $k$-means method was used, based on minimizing Euclidean distances to the centers of the clusters.

For the analytical presentation of models to determine the innovation level, the discriminant analysis was used. The categorical dependent variable was presented by the innovation level corresponded to clusters 1-3 and independent variables corresponded to the significant cluster variables for $X 2.1-X 2.6, X 2.9-X 2.11, X 2.15$, $X 2.16, X 2.18$, and $X 2.19$ (Table 2). The statistical significance of the discriminant analysis is confirmed by the values of the $F$-criterion and $p$ level for indicators $X 2.1-X 2.6, X 2.9-X 2.11, X 2.15$, $X 2.16, X 2.18, X 2.19$ ( $F>$ Fcrit ., p-level $\rightarrow$ o), as well as the percentage of correct classification for the source data set, which comprises $100 \%$. Cluster and discriminant analysis were conducted in Statistica 12.0.

\section{RESULTS}

\section{Social and Demographic Portrait of a Farmer Entrepreneur}

According to the answers to the first block questions, the researchers obtained the results that reflect the social and demographic characteristics of farmers. It was revealed that people aged from 31 to 40 comprise more than $50 \%$ of the respondents, and people aged from 18 to 30 comprise a quarter of the respondents. Accordingly, it can be stated that the key characteristics of the social portrait of a modern Russian innovative farmer will correspond to the traits of people of this age category. External conditions are important for the formation of personality and human behavior. The ratio of the number of farmers born in a city with a 
population of 1 million or more is approximately equal to those born in small towns and rural areas. This situation indicates relatively equal initial conditions, considering the fact that the vast majority of the community was born and brought up in the Soviet times.

The results of the survey showed that only one fifth of the studied community did not have siblings. Besides, there were more married farmers in the sample than unmarried ones. Thus, we can observe the developed cooperation and teamwork skills, unselfishness, flexibility of thinking and behavior, developed communication skills, etc. To confirm these results, the presence of siblings and children in the families of farmers entrepreneurial was also examined. The predominant part of the farmers, i.e., $60 \%$ is married or have siblings. It is worth highlighting the prevalence of large families among farmers. Thus, $70 \%$ of respondents came from families which had from two to four children. The parental status of a farmer entrepreneur is also a significant characteristic of the economic portrait. About $60 \%$ of the entrepreneurs have children, while $80 \%$ of them have two or more children. This fact confirms the awareness of the decision to have children and high degree of responsibility and determination of the farmers entrepreneurs.

The majority of respondents (40\%) majored in economy. Most of the respondents are engaged in IT or consulting. In the terms of economy digitalization, these areas are highly correlated.

The vast majority of respondents (70\%) often use a laptop in their work. Most of the studied universe rarely uses a tablet to search for information and to solve operational problems. The use of a smartphone is more preferable in this community. There is a high mobility of respondents and the frequency of using the Internet. Most of the respondents (40\%) spend from two to four hours a day on the Internet. At the same time, another $40 \%$ of respondents admitted that they spend more than 4 hours a day on the Internet. The vast majority (70\%) does not watch TV, and the rest of the respondents watch television programs for less than 2 hours a day. This shows a decrease in the importance of this channel of information distribution.

\section{The Study of Farmers as Innovators in} Entrepreneurship

According to the results of the cluster analysis, there were identified three clusters of farmers by the level of innovation development. The indicators $X 2.1-X 2.6, X 2.9-X 2.11, X 2.15, X 2.16$, $X .18, \quad X 2.19$ and the answers to the corresponding questions were significant for clusterization. The variance analysis of clustering indicators is introduced in Table 2.

Table 2. The results of the variance analysis of clustering indicators of the Russian farmers by the level of innovation.

\begin{tabular}{lllllll}
\hline Variable & BetweenSS & df & WithinSS & df & F & signif. p \\
\hline$X 2.1$ & 12.36 & 2 & 9.97 & 899 & 7.09 & 0.0083 \\
$X 2.2$ & 26.14 & 2 & 18.46 & 899 & 36.71 & 0.0000 \\
$X 2.3$ & 9.45 & 2 & 7.11 & 899 & 6.37 & 0.0106 \\
$X 2.4$ & 15.68 & 2 & 5.98 & 899 & 49.08 & 0.0000 \\
$X 2.5$ & 4.99 & 2 & 3.48 & 899 & 5.69 & 0.0131 \\
$X 2.6$ & 34.1 & 2 & 28.53 & 899 & 22.98 & 0.0000 \\
$X 2.9$ & 16.84 & 2 & 11.94 & 899 & 16.74 & 0.0000 \\
$X 2.10$ & 11.39 & 2 & 6.22 & 899 & 20.39 & 0.0000 \\
$X 2.11$ & 20.01 & 2 & 16.48 & 899 & 10.68 & 0.0007 \\
$X 2.15$ & 16.66 & 2 & 14.29 & 899 & 6.98 & 0.0094 \\
$X 2.16$ & 14.38 & 2 & 10.28 & 899 & 12.48 & 0.0001 \\
$X 2.18$ & 13.76 & 2 & 9.43 & 899 & 13.39 & 0.0000 \\
$X 2.19$ & 20.48 & 2 & 11.08 & 899 & 7.02 & 0.0089 \\
\hline
\end{tabular}


The introduced indicators are statistically significant for clustering by the between-group variance index, the values of which exceed the within-group variance index (Between SS> Within SS); for F-criterion, the calculated values of which exceed the critical 3.0 with the number of degrees of freedom $(2 ; 899)$ at $p=0.05$. The analysis showed that the most important features of the innovative farmer are professional adherence, autonomy, responsibility, leadership, optimism, flexibility and rationality.

According to the results of the cluster and discriminant analysis, a system of function (1) was developed. It represents the methodological basis to determine the innovation level of Russian farmers:

$$
\left\{\begin{array}{c}
I_{1}=0.71 \times X 2.1+1.11 \times X 2.2+0.66 \times X 2.3+1.26 \times X 2.4+0.47 \times X 2.5+ \\
+1.06 \times X 2.6+0.94 \times X 2.9+1.01 \times X 2.10+0.78 \times X 2.11+0.7 * X 2.15+ \\
+0.81 \times X 2.16+0.88 \times X 2.18+0.68 \times X 2.19-13.94 \\
I_{2}=0.54 \times X 2.1+0.89 \times X 2.2+0.48 \times X 2.3+1.08 \times X 2.4+0.38 \times X 2.5+ \\
+0.78 \times X 2.6+0.66 \times X 2.9+0.73 \times X 2.10+0.55 \times X 2.11+0.52 * X 2.15+ \\
+0.6 \times X 2.16+0.64 \times X 2.18+0.51 \times X 2.19+3.19 \\
I_{3}=0.33 \times X 2.1+0,63 \times X 2.2+0.26 \times X 2.3+0.97 \times X 2.4+0.21 \times X 2.5+ \\
+0.58 \times X 2.6+0.49 \times X 2.9+0,55 \times X 2.10+0.36 \times X 211+0.29 * X 2.15+ \\
+0.4 \times X 2.16+0.42 \times X 2.18+0.32 \times X 2.19+14.05
\end{array}\right.
$$

The classification is based on the values of the integral indicators $I_{1}-I_{3}$. The respondent belongs to the class, where the calculated value of indicator $I$ is the highest among $I_{1}-I_{3}$. The integral indicator $I_{1}$ corresponds to the first class, indicator $I_{2}$ corresponds to the second class, indicator $I_{3}$ to the third class.
Characteristics of the entrepreneurs' types within the economic system "innovator vs. conservative" by the example of farmers in the agricultural sector of Russia are introduced in Table 3.

Table 3. Characteristics of the entrepreneurs' types within the economic system "innovator vs. conservative"

\begin{tabular}{|c|c|c|c|c|c|c|c|c|c|c|c|c|c|c|c|}
\hline \multirow[b]{2}{*}{ Class } & \multirow[b]{2}{*}{$\begin{array}{l}\text { Entreprene } \\
\text { ur's Type }\end{array}$} & \multirow{2}{*}{$\begin{array}{l}\text { Number } \\
\text { of } \\
\text { Represe } \\
\text { ntatives, } \\
\%\end{array}$} & \multicolumn{13}{|c|}{ Average Values } \\
\hline & & & $\begin{array}{c}x 2 . \\
1\end{array}$ & $\begin{array}{l}x 2 . \\
2\end{array}$ & $\begin{array}{l}x 2 . \\
3\end{array}$ & $\begin{array}{l}x 2 \\
4\end{array}$ & $\begin{array}{l}x 2 \\
5\end{array}$ & $\begin{array}{l}x 2 . \\
6\end{array}$ & $\begin{array}{l}x 2 . \\
9\end{array}$ & $\begin{array}{r}x 2 . \\
10\end{array}$ & $\begin{array}{r}X 2 \\
11\end{array}$ & $\begin{array}{r}X 2 . \\
15\end{array}$ & $\begin{array}{r}X 2 . \\
16\end{array}$ & $\begin{array}{l}X 2 . \\
18\end{array}$ & $\begin{array}{r}X 2 \\
19\end{array}$ \\
\hline 1 & Innovative & 0.7 & 6.7 & 5.9 & 6.9 & 8.2 & 8.1 & 6.2 & 6.2 & 7.3 & 5.6 & 5.6 & 5.9 & 6.8 & 6.5 \\
\hline 2 & Transitive & 13.2 & 5.4 & 4.9 & 5.7 & 7.2 & 6.9 & 5.2 & 5.5 & 6.0 & 4.6 & 4.8 & 5.0 & 5.6 & 4.8 \\
\hline 3 & $\begin{array}{l}\text { Conservativ } \\
\mathrm{e}\end{array}$ & 86.1 & 1.7 & 2.9 & 2.0 & 3.9 & 3.1 & 2.6 & 3.5 & 3.0 & 3.4 & 2.8 & 2.9 & 3.3 & 2.1 \\
\hline
\end{tabular}

High-level features of the innovator were performed by $0.7 \%$ (6) respondents. Only 119 farmers $(13.2 \%)$ have the characteristics of the transitive type of entrepreneurship. For this category, the average values characterizing the innovation level are 4.6-7.2, while the highest possible level is 10 . Most of the farmers (775 respondents, i.e., $86.1 \%$ ) belong to the class of the conservatives. The average values are 1.73.9.
The indicators according to the entrepreneur's type are introduced in Table 4 . The indicator levels for the transitive type are defined as the interval of the actual values for the second class of indicators. Since the indicator values are variable, a confidence interval was determined. Indicator values vary there with a probability of 95\%. The range of indicator values for the "conservative" type is defined as the indicator values that are lower than for the "transitive" 
type, and for the "innovative" type, they are defined as above the "transitive" type.

Table 4. The estimation indicators values for the category of farmer entrepreneur.

\begin{tabular}{|c|c|c|c|}
\hline \multirow{2}{*}{$\begin{array}{l}\text { Indica } \\
\text { tor }\end{array}$} & \multicolumn{3}{|c|}{ Farmer Entrepreneur Category } \\
\hline & $\begin{array}{l}\text { Conservat } \\
\text { ive }\end{array}$ & $\begin{array}{l}\text { Transit } \\
\text { ive }\end{array}$ & $\begin{array}{l}\text { Innovat } \\
\text { ive }\end{array}$ \\
\hline$X 2.1$ & $<4.6$ & $4.6-6.5$ & $>6.5$ \\
\hline$x 2.2$ & $<4.2$ & $4.2-5.8$ & $>5.8$ \\
\hline$X 2.3$ & $<4.5$ & $4.5-6.6$ & $>6.6$ \\
\hline$X 2.4$ & $<5.8$ & $5.8-8.0$ & $>8.0$ \\
\hline$X 2.5$ & $<5.3$ & $5.3-8.0$ & $>8.0$ \\
\hline$X 2.6$ & $<4.0$ & $4.0-6.0$ & $>6.0$ \\
\hline$X 2.9$ & $<4.2$ & 4.2-6.1 & $>6.1$ \\
\hline$X 2.10$ & $<4.5$ & $4.5-7.1$ & $>7.1$ \\
\hline$X 2.11$ & $<3.7$ & $3.7-5.4$ & $>5.4$ \\
\hline$X 2.15$ & $<3.9$ & $3.9-5.5$ & $>5.5$ \\
\hline$X 2.16$ & $<4.2$ & $4.2-5.8$ & $>5.8$ \\
\hline$X 2.18$ & $<4.4$ & 4.4-6.5 & $>6.5$ \\
\hline$X 2.19$ & $<3.5$ & $3.5-6.0$ & $>6.0$ \\
\hline
\end{tabular}

\section{DISCUSSION}

In the context of the empirical study conducted, a new tool was developed to identify the types of entrepreneurs within the "innovator vs. conservative" economic system by the example of farmers in Russian agricultural sector. This approach was introduced by means of a discriminant model, taking into account the social and demographic characteristics of the entrepreneur, as well as the tendency to implement innovations. The research was focused only on the determination of the interaction of innovators and conservatives in the micro- and macro-systems (Mthanti \& Ojah, 2017; Youssef, Boubaker \& Omri, 2018; Dvouletý, 2018; Cipollone \& Giordani, 2019), as well as their characteristics (Newman et al., 2018; Jones \& Barnir, 2019; Neneh, 2019; Cipollone \& Giordani, 2019; Paul \& Shrivatava, 2016; Klein, 2016). The present research can supplement the existing scientific results in the aspect of study of the innovative development of the economy. The introduced model provides an opportunity to determine quantitatively the structure of economic agents within the "innovator vs. conservative" system, basing on a comprehensive consideration of the individual and social and demographic characteristics of the entrepreneur (Aeeni et al., 2019; Zaremohzzabieh et al., 2019; Mthanti \& Ojah, 2017; Youssef, Boubaker \& Omri, 2018; Cipollone \& Giordani, 2019; Klein, 2016). In addition, the results of the practical application of this model for assessing the categories of entrepreneurs allow us to obtain reliable data corresponding to the latest trends in the business development and the entrepreneurs' reaction to a changing environment, taking into account the development of the abilities for innovative thinking and action. The present model is universal, since it allows us to evaluate the categories of entrepreneurs within the national economic system, in any sector of the economy as well as within a particular enterprise. The adequacy and practical implications of the introduced model is proved by means of the statistical characteristics of the econometric model.

The definition of entrepreneurs' categories, i.e., innovative, transitive and conservative allows us to determine the qualitative structure of the business environment. Therefore, it provides timely and effective measures to improve the efficiency of the industry, to develop the targeted tools and strategies that ensure its sustainable innovative development. Besides, it provides the balance between the categories of farmers entrepreneurs, which determines the stability of the economic growth within the agriculture sector.

The results of the present study are of practical value but cannot be applied for the analysis of other industries and territories, since the sample of respondents is concentrated within a specified industry. Besides, in the context of the present study, the researchers did not consider the qualitative characteristics of farmers entrepreneurs, depending on their categories, as well as the optimal ratio of innovators and conservatives in agriculture. Since these aspects are quite fundamental, further research will be focused on these issues precisely.

\section{CONCLUSION}

According to the results of the empirical study, set tasks were solved and the following scientific results were obtained. The practical value of the model for assessing the category of 
farmers entrepreneurs includes the justification that the number of conservative farmers prevail in agriculture sector in Tver, Kursk, Tambov, Penza, Arkhangelsk, Kurgan, Leningrad regions, and Yakutia There was observed $0.7 \%$ of innovators in the industry. Only $13.2 \%$ of farmers entrepreneurs are trying to change their behavior from conservative to innovative and to implement new standards, which are becoming the most attractive ones. The existing structure of the categories of farmers in the industry indicates the absolute unevenness of the categories of entrepreneurs in the studied regions, as well as in Russia as a whole, since these regions are represented by the middle level of innovation, which is the most typical for Russia. The inequality of entrepreneurs' categories leads to a negative trend in the agriculture development and affects the innovative potential of the industry. It is worth highlighting that the dependence on state subsidies in terms of resources deficiency to reveal innovative potential in the agroindustrial complex can be detrimental for the development of the rural economic system. The risk of crisis in the industry or a decrease in the growth rate and the level of social development of the territory were determined. Consequently, government policy should provide the efficient identification and development of the innovative potential of farmers entrepreneurs who may form the innovation-based development of the agricultural industry.

\section{SUPPORTING AGENCY}

The study was carried out with the financial support of The Russian Foundation for Basic Research in the framework of the scientific project No. 20-010-00457 "A development of theoretical and methodological foundations for the transformation of social and labor relations in agriculture in the context of the digital economy development".

\section{REFERENCES}

Adukov, R.Kh., \& Aidinova, A.T. (2016). Socioeconomic portrait of a modern farmer: evaluation and ways to improve the characteristics and economic conditions. Stavropol AIC Bulletin, P3, 4-9.
Aeeni, Z., Motavaseli, M., Sakhdari, K., \& Dehkordi, A.M. (2019). Baumol's theory of entrepreneurial allocation: A systematic review and research agenda. European Research on Management and Business Economics, 25, 30-37. https://doi.org/10.1016/j.iedeen.2018.09.00 1.

Al-Hashimy, H.N.H., Al Jubair, A.S., \& Jasim, E.T. (2019). The effect of accounting information systems (AIS) on enterprise resource planning (ERP). Journal of Southwest Jiaotong University, 54. https://doi.org/10.35741/issn.02582724.54.5.36.

Avksent'ev, N., Bozhechkova, A., Kaukin, A., Miller, E., Nazarov, V., Sokolov, I., Trunin, P., \& Uzun, V. (2019). Monitoring of Russia's economic outlook. Trends and challenges of socio-economic development. Institute of Economic Policy named after E.T. Gaidar, The Russian Presidential Academy of National Economy and Public Administration under the President of the Russian Federation. http://www.iep.ru/files/text/crisis_monitori ng/2019_16-99_October.pdf.

Buzdalov, I.N. (2016). Methodological aspects of sustainable rural development. Scientific Works of the Free Economic Society, 197, 262-267.

Cipollone, A., \& Giordani, P.E. (2019). Market frictions in entrepreneurial innovation: Theory and evidence. Journal of Economic Behavior \& Organization, 163, 297-331. https://doi.org/10.1016/j.jebo.2019.04.028.

Deloitte. (2019). Agricultural market review. https://www2.deloitte.com/content/dam/De loitte/ru/Documents/consumerbusiness/russian/obzor-rynka-selskogohozyajstva-2019.pdf.

Drucker, P.F. (2008). Managing oneself (Harvard business review classics). Cambridge: Harvard Business Press.

Dvouletý, O. (2018). How to analyze determinants of entrepreneurship and selfemployment at the country level? A methodological contribution. Journal of Business Venturing Insights, 9, 92-99. https://doi.org/10.1016/j.jbvi.2018.03.002. 
Gunyakov, Y., \& Gunyakov, D. (2013). Restructuring and innovative business. Journal of Contemporary Economics Issues, 2. https://doi.org/10.24194/21314.

Jones, R.J., \& Barnir, A. (2019). Properties of opportunity creation and discovery: Comparing variation in contexts of innovativeness. Technovation, 79, 1-10. https://doi.org/10.1016/j.technovation.2018. 02.014 .

Klein, P.G. (2016). Why entrepreneurs need firms, and the theory of the firm needs entrepreneurship theory. Revista de Administração, 51, 323-326. https://doi.org/10.1016/j.rausp.2016.06.007.

Kostyaev, A.I. (2018). On the paradigm of rural development. Fundamental and Applied Research of the Cooperative Sector of the Economy, 6, 3-12.

Maidique, M.A. (1980). Entrepreneurs, champions, and technological innovation. Sloan Management Review, 21, 59-59.

Markham, S.K. (2000). Corporate championing and antagonism as forms of political behavior: An R\&D perspective. Organization Science, 11, 429-447.

https://doi.org/10.1287/orsc.11.4.429.14599.

Mazur, V.V., Barmuta, K.A., Demin, S.S., Tikhomirov, E.A., \& Bykovskiy, M.A. (2016). Innovation clusters: Advantages and disadvantages. International Journal of Economics and Financial Issues, 6, 270-274.

Mthanti, T., \& Ojah, K. (2017). Entrepreneurial orientation (EO): Measurement and policy implications of entrepreneurship at the macroeconomic level. Research Policy, 46, 724-739. https://doi.org/10.1016/j.respol.2017.01.012

Neneh, B.N. (2019). From entrepreneurial alertness to entrepreneurial behavior: The role of trait competitiveness and proactive personality. Personality and Individual Differences, 1381, 273-279. https://doi.org/10.1016/j.paid.2018.10.020.

Neskorodeva, I.I., \& Pustovgar, S.A. (2015). An Approach to Predicting the Insolvency of Ukrainian Steel Enterprises Based on Financial Potential. Journal of Eastern
European and Central Asian Research, 2(2), 33-43.

https://doi.org/10.15549/jeecar.v2i2.104

Newman, A., Tse, H.H.M., Schwarz, G., \& Nielsen, I. (2018). The effects of employees' creative self-efficacy on innovative behavior: The role of entrepreneurial leadership. Journal of Business Research, 89, 1-9. https://doi.org/10.1016/j.jbusres.2018.04.00 1.

Nikolaeva, I. (2014). Marketing aspects of innovative development of priority traditional industries of agribusiness of Republic of Sakha (Yakutia). Journal of Contemporary Economics Issues, 3. https://doi.org/10.24194/31402.

Novikova, N.V., Barmuta, K.A., Kaderova, V.A., Il'Yaschenko, D.P., Abdulov, R.E., \& Aleksakhin, A.V. (2016). Planning of new products technological mastering and its influence on economic indicators of companies. International Journal of Economics and Financial Issues, 6, 65-70.

Paul, J., \& Shrivatava, A. (2016). Do young managers in a developing country have stronger entrepreneurial intentions? Theory and debate. International Business Review, 25, 1197-1210. https://doi.org/10.1016/j.ibusrev.2016.03.00 3.

Roscongress. (2018). Ranking of innovative regions of Russia 2018.

https://roscongress.org/en/materials/reyting -innovatsionnykh-regionov-rossii-versiya2018/.

Say, J.B. (2018). A Treatise on Political Economy. Volume 1. Hard Press.

Schon, D.A. (1963). Champions for radical new inventions. Harvard Business Review, 41, 77-86.

Schumpeter, J.A. (2008). Capitalism, Socialism, and Democracy. New York: Harper Perennial Modern Classics.

Sharapova, V.M. (2017). Scientific basis of the rural entrepreneurship development. Theory and Practice of World Science, 5, 10 14.

Shutkov, A.A. (2019). The System of AgroIndustrial Complex Management: Theory, 
Methodology, Practice. Moscow: Publishing and Trading Corporation "Dashkov y K".

TASS Russian News Agency. (2020). Farmers produce almost half of all Russian agricultural products.

https://tass.ru/ekonomika/5243142.

The Russian Government. (2012). State program of agricultural development and regulations for markets of agricultural products, raw materials and food in 2013-2020. http://government.ru/rugovclassifier/815/ev ents/.

Vu, N.T., Bien, B.X., Thai, T.M., Hai, T.V., \& Hung, N.T. (2019). How to enhance firm performance: The case of small and medium enteprises in Vietnam. Journal of Southwest Jiaotong University, 54. https://doi.org/10.35741/issn.02582724.54.6.34.

Witte, E. (1977). Power and innovation: A twocenter theory. International Studies of Management and Organization, 7, 47-70.

Xie, H., Huang, Y., Chen, Q., Zhang, Y., \& Wu, Q. (2019). Prospects for agricultural sustainable intensification: A review of research. Land, 8, 157. https://doi.org/10.3390/land8110157

Youssef, A.B., Boubaker, S., \& Omri, A. (2018). Entrepreneurship and sustainability: The need for innovative and institutional solutions. Technological Forecasting and Social Change, 129, 232-241. https://doi.org/10.1016/j.techfore.2017.11.0 03.

Zaremohzzabieh, Z., Ahrari, S., Krauss, S.E., Samah, A.A., Meng, L.K., \& Ariffin, Z. (2019). Predicting social entrepreneurial intention: A meta-analytic path analysis based on the theory of planned behavior. Journal of Business Research, 96, 264-276. https://doi.org/10.1016/j.jbusres.2018.11.03 0 .

\section{ABOUT THE AUTHORS}

Alexander Semin, email: semin.alexander.useu@gmail.com

Dr. Alexander Semin is a Professor at Ural State Economic University, Yekaterinburg, Russia.

Dr. Mikhail Kislitskiy is a Professor at AllRussian Research Institute of Agricultural Economics, Moscow, Russia. 